\title{
NATURAL OPIUM AS ONE OF THE POSSIBILITIES FOR DRUG ABUSERS
}

\author{
Hana Klusoňováa, Jana Vlkováa, Peter Višňovskýb \\ a Department of Biological and Medical Sciences, Faculty of Pharmacy in Hradec Králové, Charles University in Prague, \\ Hradec Králové, Czech Republic \\ ${ }^{b}$ Department of Pharmacology and Toxicology, Faculty of Pharmacy in Hradec Králové, Charles University in Prague, \\ Hradec Králové, Czech Republic \\ e-mail: klusono@faf.cuni.cz
}

Received: June 10, 2005; Accepted: September 25, 2005

Key words: Opium/Drug abuse/Anonymous questionnaire

Natural opium is a popular seasonal alternation for substance dependent people. Its processing, way of using, experience and change of habits was the aim of our study carried out via anonymous questionnaire and directed interview. 47 questionnaires were obtained. According to our results natural opium has been abused by people 19-42 years old, more than a half of them were male. Basic drug were pervitin in $57 \%$, marihuana in $33 \%$, a considerable part ( $30 \%)$ was natural opium. Each grower produced approximately $35 \mathrm{~g}$ of raw opium in one season. The most frequent way of application was smoking, injecting and "opium tea" drinking. Almost a half of the clients (40\%) felt attenuation after application; relaxation, hallucination and central stimulation admitted $25 \%$ of respondents. Health troubles had majority of the users. Combinations of natural opium with other drugs (alcohol, marihuana, pervitin) declared $45 \%$ respondents, the effects of the combinations admitted one third of users. The examination for viral hepatitis confirmed more than a half of the clients; the major part of users from Olomouc, but only $25 \%$ of users from Prostějov were tested for HIV. Opium consumption influenced habits of personal hygiene of more than a half of the users (57\%). Routine servicing of the spot of the needle insertion practiced a half of the responders. Majority of the abusers (79\%) obtained and closed out paraphernalia throw to the "harm reduction" program.

\section{INTRODUCTION}

According to staff of Contact Centers (CC) in Olomouc and Prostějov, July and August are known as "opium months". Clients of these CC - substance dependent persons - use to travel in the fields to search for poppy (Papaver somniferum). They try to obtain raw opium from these plants because of morphine contained in it. Natural opium is the substance they are abusing ${ }^{1}$. Our aim was to find out the way how the clients use raw opium during processing, which form is typical for abusing, what sort of experience they get after the application, whether there are different effects during mixing opium with another drugs and in which way the abuse of opium changes their habits.

\section{MATERIAL AND METHODS}

Our study was carried out in CC Walhalla in Olomouc (OL) and in CC Želva in Prostějov (PV) from August to November 2004. We acquired the data by direct interview and anonymous questionnaire. We obtained 47 questionnaires, 27 in CC Walhalla and 20 in CC Želva. The age of responding clients from Olomouc ranged between 19-42 years (mean age 25.7 years), 17 men and 10 women. The age of responding clients from Prostějov ranged between
19-37 years (mean age 26.1 years), 12 male and 8 female.

\section{RESULTS}

All respondents except three came from Olomouc region, their nationality was Czech. Most frequently they lived with their parents / family (OL $37.0 \%$, PV $45.0 \%$ ) or alone (OL $40.7 \%$, PV $35.0 \%)$. About $10 \%$ clients of both CC lived with friends or partners. While none of respondents from Prostějov was homeless, this situation admitted $25.9 \%$ of Olomouc opium users. $37.0 \%$ clients of CC Walhalla and $25.0 \%$ clients of CC Želva lived together with drug abusing persons. Only basic education reached $40.7 \%$ respondents from Olomouc and $30.0 \%$ respondents from Prostějov. Secondary school without /with final examination finished $33.3 \%$ vs $22.2 \%$ clients of CC Walhalla and $35.0 \%$ vs $30.0 \%$ clients of Želva. Permanent job reported $1 / 4$ of clients from Prostějov but only $11.1 \%$ of clients from Olomouc. Approximately $20 \%$ respondents of both CC worked occasionally, registered at Work Office or unemployed without the registration were $44.4 \%$ vs $14.8 \%$ clients from Olomouc and $40.0 \%$ vs $5.0 \%$ clients from Prostějov. More than half of both $\mathrm{CC}$ clients voluntarily absolved the examination for viral hepatitis: $63.0 \%$ opium users from Olomouc and 
$60.0 \%$ opium users from Prostějov. While examination for HIV reported more than half of clients from Olomouc (59.3\%), 75.0\% clients from Prostějov have not been examined. Respondents of CC Walhalla routinely abused cannabis (84.2\% smoking, $15.8 \%$ dipping sniffing), pervitin ( $68.4 \%$ by injection, $21.1 \%$ smoking), braun $(21.1 \%$ smoking, $10.5 \%$ orally, $5.3 \%$ by injection), inhalation substances $21.1 \%$; both medicaments and/or cigarettes each $15.8 \%$; heroin (smoking), ecstasy, LSD, alcohol each $10.5 \%$, and mushrooms $5.3 \%$. On the contrary, clients of CC Želva preferred spirits (77.8\%), pervitin (66.7\% by injection), cigarettes (55.6\%), cannabis ( $44.4 \%)$, least frequently braun ( $11.1 \%$ smoking, $11.1 \%$ by injection) and medicaments $(22.2 \%)$. The basic illegal drug for majority respondents was pervitin (OL 63.0\%, PV 50.0\%); the initial drug abused was marihuana.

About a half of the respondents were new natural opium users with experience less than one year (OL 50\%, PV $44.4 \%$ ); $33.3 \%$ respondents has been abusing this drug for more than three years. Majority of abusers allegedly obtained the drug easily (OL 77.9\%, PV 66.7\%); $22.2 \%$ respondents consumed opium occasionally. Interestingly, while clients of CC in Olomouc preferred their own collection and processing of opium ( OL $51.9 \%$, PV $35.0 \%$ ), clients of CC in Prostějov obtained natural opium per contact persons (O1 33.3\%, PV 50\%). Approximately $15 \%$ of both CC clients did not indicate the way of obtaining the drug. Majority of users (OL 72.6\%, PV 75.1\%) obtained natural opium due to scoring pods and curettaging dried sap; others (OL 27.4, PV 24.9\%) collected whole cupolas. The abusers who administered opium by injection dried the opium sap and solved it on the spoon with water and citric acid. Clients that preferred smoking used dry opium. The users of "opium tea" dried the collected cupolas and prepared the drink (Table 1).

The users' experience with natural opium summarizes the Table 2. While clients of CC in Prostějov claim that effect of natural opium was the same during the whole opium season, $25 \%$ of clients of CC in Olomouc admitted that the opium obtained in the beginning of the season was of better quality.

Half of the respondents consumed the drug immediately (OL $51.9 \%$, PV $58.8 \%$ ), only small number of users stored it for use after the season (OL 11.1\%, PV $17.7 \%$ ). $22.2 \%$ clients from Olomouc and $17.7 \%$ clients from Prostějov collected natural opium for another users, $14.8 \%$ and $5.9 \%$ admitted both immediate consumption and collecting for another users. Respondents of both $\mathrm{CC}$ did not mix natural opium with other substances, but some of the users mixed it with marihuana (THC), pervitin, toluene, or with alcohol (Table 3 and 4).

Clients stated different amounts of opium as necessary for one application. The biggest group of users from Olomouc (40.9\%) needed 10-20 cupolas for one application, $1 / 4$ of users needed $20-30$ pods and the same number admitted 30-40 cupolas. Natural opium users from Prostějov stated most frequently $20-30$ pods (38.5\%), almost $1 / 3$ counted $30-40$ cupolas and $15.4 \%$ needed 10-20 pods. $9.1 \%$ of the respondents from CC Walhalla and $15.4 \%$ of the respondents from CC Želva were not able to state exactly the consumption of pods for one application. For "opium tea", 15-20 cupolas per liter of water were used. It was difficult for the respondents to estimate the amount of dry opium obtained per day or during the whole opium season. They stated meanly $4 \mathrm{~g}$ per day and $40 \mathrm{~g}$ (Olomouc's users) or $30 \mathrm{~g}$ (Prostějov's users) during the whole season. The respondents had only little experience with imported opium (20\%). According to the clients from Olomouc, imported opium was of higher quality, clients from Olomouc claimed similar effects as were these of domestic opium. The clients themselves doubted about the effects of natural opium use at their habits. Nevertheless, one can observe changes concerning to some of their behavioral habits (Table 5 and 6 ).

Clients obtained paraphernalia and threw them away thanks to the exchange program (OL 76.2\%, PV 81.8\%), via primary or secondary exchange or in chemist's shops. Authors consider as alarming the fact that about $10 \%$ of the respondents from each CC simply litter useless equipment. Routine servicing of spot of the needle insertion practiced almost the half of the respondents (45\%).

\section{DISCUSSION}

In our country a variety named "oil poppy" is being grown. Opium poppy grown in Asia contains about $20 \%$ of morphine. Oil poppy contains almost 5-times more oil, but very little morphine (1-3\%). It is possible to obtain $0.02 \mathrm{~g}$ of opium from one cupola ${ }^{2}$, than $10-20$ pods give 0.2-0.4 g, from 20-30 pods users can obtain 0.4-0.6 $\mathrm{g}$ and $30-40$ cupolas give $0.6-0.8 \mathrm{~g}$ of opium. Supposed that the raw opium contains $14.5 \%$ of water ${ }^{3}$, clients can obtain after drying $0.17-0.34 \mathrm{~g}$ dry opium from $10-20$ cupolas, 0.34-0.51 g from 20-30 pods and 0.51-0.68 g from 3040 pods for a dose. Czech pharmacopoeia recommends maximum single dose $0.15 \mathrm{~g}$ of dry opium, maximum day dose $0.5 \mathrm{~g}$ of dry opium containing $10 \%$ of morphine ${ }^{4}$. Assuming that the variety growing in our country contains $1.0-3.0 \%$ of morphine, then maximum single dose can be 0.5-1.5 g and maximum day dose 1.67-5.0 $\mathrm{g}$ of opium. Then it is really possible that clients use these numbers of cupolas for one application. On the contrary, if our assumption of the amount of morphine is correct, then our respondents need less of active substance than is the maximum dose. There could be also another explanation: one cupola gives more natural opium - according to another literature review it is possible to obtain $0.05 \mathrm{~g}$ of opium from one pod ${ }^{5}$. Then there would be 2.5 - times higher concentration of morphine in one dose. Experience and health troubles described by the abusers confirm known effects of this drug in the organism ${ }^{6}$. One group of our clients abused natural opium together with other drugs, while a result was either the amplification or the reducing of cumulative effect. It is difficult to explain why users described contending effects. Feelings and experience are quite personal matters. It depends on health condition, actual mental state, dose of the substances, their purity and on the amount of active substance. Questions about obtaining and disposing of natural opium hid the 
Table 1. Ways of application of natural opium

\begin{tabular}{|l|c|c|}
\hline & $\begin{array}{c}\text { users from } \\
\text { Olomouc }\end{array}$ & $\begin{array}{c}\text { users from } \\
\text { Prostějov }\end{array}$ \\
\hline smoking & $42.9 \%$ & $40.0 \%$ \\
\hline injection (i.v.) & $14.3 \%$ & $26.7 \%$ \\
\hline drinking (p.o.) & $9.5 \%$ & $20.0 \%$ \\
\hline smoking, i.v., p.o. & $23.8 \%$ & $0.0 \%$ \\
\hline smoking, i.v. & $9.5 \%$ & $13.3 \%$ \\
\hline
\end{tabular}

Table 2. Experience with natural opium abusing

\begin{tabular}{|l|c|c|}
\hline & $\begin{array}{c}\text { users from } \\
\text { Olomouc }\end{array}$ & $\begin{array}{c}\text { users from } \\
\text { Prostějov }\end{array}$ \\
\hline attenuation; apathy & $39.1 \%$ & $40.0 \%$ \\
\hline attenuation and itch & $8.7 \%$ & $0.0 \%$ \\
\hline central stimulation & $17.4 \%$ & $13.3 \%$ \\
\hline $\begin{array}{l}\text { relaxation } \\
\text { with hallucinations }\end{array}$ & $17.4 \%$ & $6.7 \%$ \\
\hline vomiting & $0.0 \%$ & $26.7 \%$ \\
\hline vomiting and constipation & $4.4 \%$ & $0.0 \%$ \\
\hline vomiting and somnolence & $0.0 \%$ & $13.3 \%$ \\
\hline various & $13.0 \%$ & $0.0 \%$ \\
\hline
\end{tabular}

Table 3. Mixing of natural opium and other drugs

\begin{tabular}{|l|c|c|}
\hline & $\begin{array}{c}\text { users from } \\
\text { Olomouc }\end{array}$ & $\begin{array}{c}\text { users from } \\
\text { Prostějov }\end{array}$ \\
\hline alcohol & $9.1 \%$ & $26.7 \%$ \\
\hline cannabis & $13.6 \%$ & $13.3 \%$ \\
\hline pervitin & $22.7 \%$ & $6.7 \%$ \\
\hline cannabis, pervitin & $13.6 \%$ & $0.0 \%$ \\
\hline cannabis, pervitin, toluene & $4.4 \%$ & $0.0 \%$ \\
\hline not mixing & $36.4 \%$ & $53.3 \%$ \\
\hline
\end{tabular}

problems concerning illegal distribution (e.g. the re-distribution to other persons - one group of clients obtained natural opium from a dealer). Natural opium as well as every substance of abuse is an article of business. Sharing of the needles is very risky behaviour because of infectious diseases, especially viral hepatitis and HIV ( ref. $^{7}$ ). The main cause of risky behaviour is the inaccessibility of clean paraphernalia at the place and time of application, what could undermine the paraphernalia sharing ${ }^{8}$.

\section{CONCLUSION}

As the results from investigations in Olomouc and Prostějov regions show, natural opium abusing is as dangerous for both the users and general population as other substances of abuse, especially during the "opium period". Program "Harm Reduction" seems to be the most effective way of intervention for these users ${ }^{9}$.
Table 4. Influence of natural opium at other drugs

\begin{tabular}{|l|c|c|}
\hline & $\begin{array}{c}\text { users from } \\
\text { Olomouc }\end{array}$ & $\begin{array}{c}\text { users from } \\
\text { Prostějov }\end{array}$ \\
\hline amplification & $36.4 \%$ & $13.3 \%$ \\
\hline reduction & $18.2 \%$ & $6.7 \%$ \\
\hline no influence & $45.5 \%$ & $80.0 \%$ \\
\hline
\end{tabular}

Table 5. Equipment sharing

\begin{tabular}{|l|c|c|}
\hline & $\begin{array}{c}\text { users from } \\
\text { Olomouc }\end{array}$ & $\begin{array}{c}\text { users from } \\
\text { Prostějov }\end{array}$ \\
\hline yes & $36.8 \%$ & $0.0 \%$ \\
\hline not important & $5.3 \%$ & $0.0 \%$ \\
\hline unacceptable & $57.9 \%$ & $100.0 \%$ \\
\hline
\end{tabular}

Table 6. Using of paraphernalia during opium abusing period

\begin{tabular}{|l|c|c|}
\hline & $\begin{array}{c}\text { users from } \\
\text { Olomouc }\end{array}$ & $\begin{array}{c}\text { users from } \\
\text { Prostějov }\end{array}$ \\
\hline yes, at the same level & $50.0 \%$ & $36.4 \%$ \\
\hline yes, at higher level & $0.0 \%$ & $9.1 \%$ \\
\hline yes, but less often & $11.1 \%$ & $27.3 \%$ \\
\hline “only when I have got it” & $16.7 \%$ & $9.1 \%$ \\
\hline never & $22.2 \%$ & $18.2 \%$ \\
\hline
\end{tabular}

\section{REFERENCES}

1. Davenport - Hines R. Historické počátky. In: Honba za zapomněním. BB/art. Praha, 2004. p. 15-32

2. Bečková I.: Drogová závislost opiátového typu. In: Bečková I, Višňovský P. Farmakologie drogových závislostí. Praha: Karolinum, 1999. p. 73-93

3. http://www.drogy-info.cz/article/articleprint/612/-1/73, 21.4.2005

4. Opium pulveratum. Československý lékopis 4, svazek II. Praha: Avicenum - zdravotnické nakladatelství, 1987. p. 670

5. http://www.drogovaporadna.cz/rubrika.php?rubrika=54, 25.4.2005

6. Višňovský P, Bečková I. Farmakologie psychoaktivních látek vyvolávajících závislost. In: Fendrich Z, Hrdina R, Klimtová I, Suchánková J, Šimůnek T, Tilšer I, Trejtnar F, Vopršalová M, Višňovský P, Bečková I. Farmakologie pro farmaceuty I. Praha: Karolinum, 2002. p. 156-207

7. http://www.drogy-info.cz/article/view/35 , 6. 4. 2005

8. http://dis.sananim.cz//výzkum 8.4.2005 Bém P., Minařík J., Kuda A., Hrdina P.: Rozsah sdílení injekčního náčiní a parafernálií. In: Charakteristiky rizikového chování u skryté populace problémových uživatelů drog. 1999. p. 17-21

9. Dobiášová D.: Terénní programy. In: Výroční zpráva Kontaktního centra Laxus. Hradec Králové, 2001. p. 4-9 